\title{
Assessing Avian Richness and Diversity in Different Regions of Oil Palm Plantation in Selangor, Malaysia
}

\author{
Aainaa Amir ${ }^{1,2, a^{*}}$, Hafidzi Mohd Noor ${ }^{1, b}$, Kamarul Hambali ${ }^{2, c}$ \\ ${ }^{1}$ Faculty of Agriculture, Universiti Putra Malaysia, Serdang, Selangor, Malaysia \\ ${ }^{2}$ Faculty of Earth Science, Universiti Malaysia Kelantan, Jeli, Kelantan, Malaysia. \\ E-mail address: asyazwani@umk.edu.my, bhafidzi.mohdnoor@gmail.com, kamarul@umk.edu.my
}

\begin{abstract}
Keywords: Birds, Diversity, Species Richness, Oil Palm Plantation
\end{abstract}
\begin{abstract}
Malaysia is characterized by a variety of habitats such as forests, clearings, thickets, and cropland that attract various species of birds. This study examined the bird community in terms of richness and diversity at oil palm plantations habitat. The abundance of birds was determined by using distance sampling point count method. A total of 2722 birds belonging to 38 families representing 86 species of birds were detected. Diversity analysis indicates that the species of birds in the oil palm plantation at Sungai Pelek is more diverse (Shannon-Wiener Diversity Index H; 3.52) and richness (Margalef's Richness Index R1; 10.2) than oil palm plantation in Teluk Panglima Garang-Pulau Carey and Banting-Jenjarum. However, the species of birds in the oil palm plantations at Teluk Panglima Garang-Pulau Carey and Banting-Jenjarum show higher evenness (Pielou's Evenness Index E; 0.82) compared with oil palm plantations in Sungai Pelek. The results of this study indicate that the species composition and distribution of the avian species in the oil palm plantations are affected by habitat characterization of that particular area and its vicinity.
\end{abstract}

\section{INTRODUCTION}

Malaysia bestowed with a variety of habitats such as forests, open spaces, shrublands, wetlands, lake, river, aquacultural ponds, agricultural lands, paddy fields, and waste water treatment areas [1], which is rich in diversity of birds, including 525 residents, 200 migrants, 92 vagrants, and 42 endemic bird species [2]. However, the conversion of tropical lowland forests on a large scale into oil palm plantations, especially in Southeast Asia, has led to a significant loss and fragmentation of once great and continuous tropical forest habitats [3]. Yet, many logged forests that are facing degradation are subjected to continuous pressure for conversion for agriculture, especially oil palm in Southeast Asia [4]. Forest clearings for new oil palm plantations usually results in many degraded and small patches of forest.

Felling of natural forests for agriculture has threatened the survival of many species of birds [5]. Changes in bird assemblages in undisturbed and human modified habitats have been studied in different parts of the world by several authors [6,7,8,9]. Approximately, 45 species of birds are endangered from loss and degradation of habitats in Malaysia [10]. Reducing the loss of habitat is more effective than trying to boost bird populations in their foraging areas and then restoring the habitat.

The retention of forest patches in oil palm plantations, especially those with High Conservation Value (HCV) has been promoted by the Roundtable on Sustainable Palm Oil (RSPO) certification program as a means to reduce the loss of biological diversity in and around oil palm plantations [11]. Despite, its overall effectiveness has not been widely demonstrated; such strategy is usually considered as a useful practice to improve biodiversity and is part of the "wildlife-friendly" management system in the oil palm plantations [12]. Only a few studies have specifically examined the value of forest patches in habitat matrix of oil palm for vertebrate conservation.

Therefore, conservation of natural habitats across the country is the most important factor in maintaining bird populations. It also has been suggested that the value of agricultural plantations for bird conservation can be enhanced by maintaining forest patches within or nearby plantation [13], although the results were not always consistent [14]. 
The main objective of this study was to investigate the contribution of biological diversity in human-modified habitats; using oil palm plantation as a model and by using birds as indicators. The main objective has been achieved by analysing the richness and diversity of bird species in each sites of the study area. Therefore, parameters such as relative abundance, composition, and diversity are expected to improve our understanding of the effects of habitat structure and its vicinity on bird species.

\section{MATERIALS AND METHODS}

Study Area. The study regions were located in the state of Selangor. The data was collected from three regions; Teluk Panglima Garang-Pulau Carey $\left(2^{0} 56.477^{\prime} \mathrm{N}, 101^{0} 25.261^{\prime} \mathrm{E}\right)$, Banting-Jenjarom $\left(2^{0} 50.767^{\prime} \mathrm{N}, 101^{0} 25.298^{\prime} \mathrm{E}\right)$, and Sungai Pelek (2³9.856’ $\left.\mathrm{N}, 101^{\circ} 44.521^{\prime} \mathrm{E}\right)$. Each study region is composed of oil palm plantation that is adjacent or continuous with the mangrove area (Fig.1).

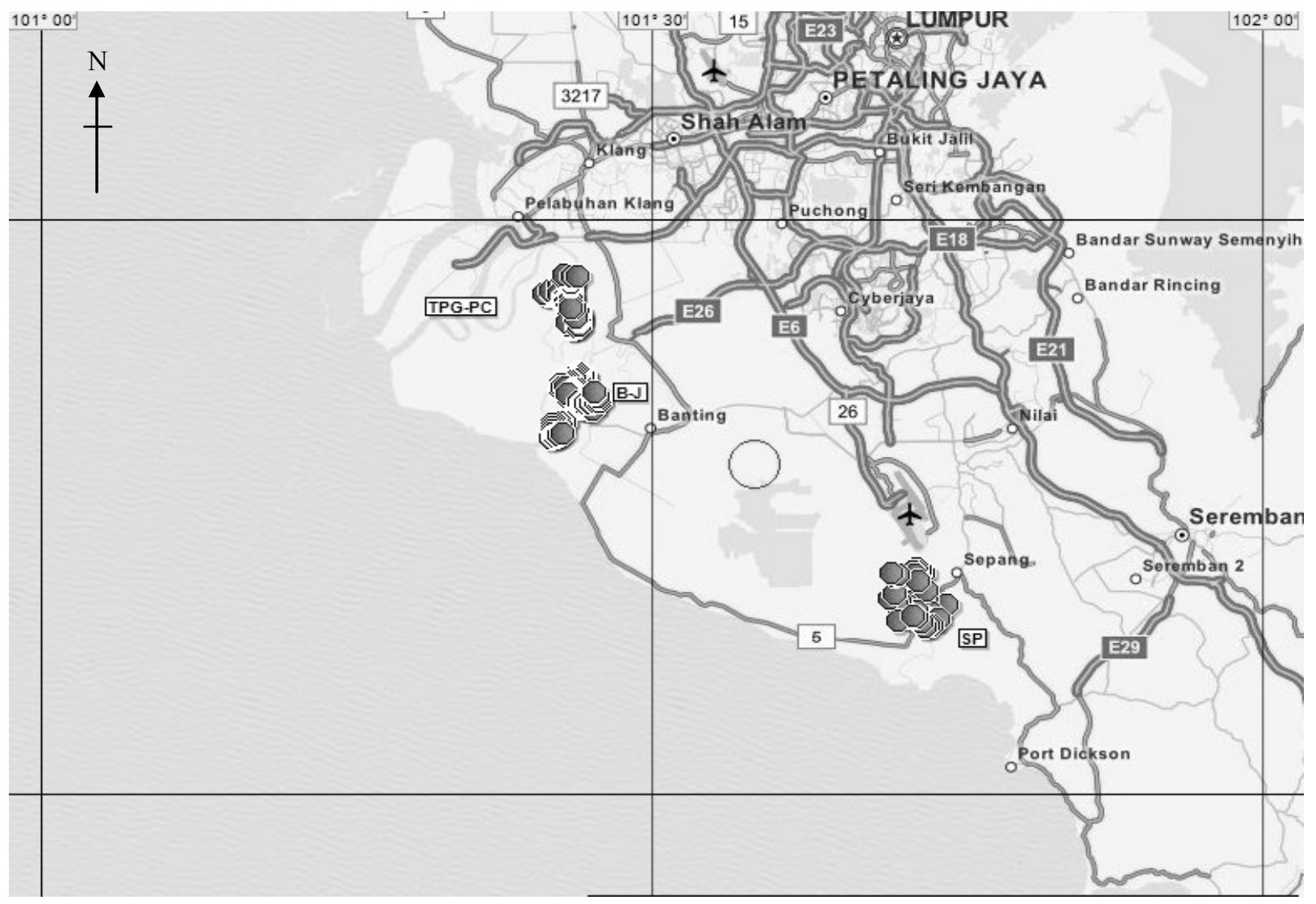

Fig. 1. Geographical locations and map of the study areas. Circles represent of the survey plots. TPG-PC is represent for Teluk Panglima Garang-Pulau Carey, B-J is for Banting-Jenjarom and SP is stand for Sungai Pelek.

Bird Surveys. To determine the richness and diversity of resident bird communities, bird surveys were conducted using the Point Count technique at each study sites from October 2012 to November 2013. Each sampling conducted at a particular site covered 80 point counts. All bird surveys were carried out by the same observer [15]. The sampling points were chosen randomly with the condition that they were at least $200 \mathrm{~m}$ apart [16]. During each survey, birds that were seen or heard during a 10 minutes period within $40 \mathrm{~m}$ radius were recorded at each sampling point [17]. All surveys were conducted between 0700 and $1030 \mathrm{~h}$ on days with no precipitation or strong wind [15]. If a bird was heard and could not be identified, the calls were documented using a voice recorder, and compared with local bird vocalization from a CD-ROM of Birds of Tropical Asia 3 [18]. 


\section{DATA ANALYSIS}

Relative Abundance (\%). The relative abundance relates to the number of individuals of a particular species as a percent of total detection at each area. We estimate the relative abundance for each species detection by using average values which is calcualted by dividing the total number of species detected in each region. The relative abundance (\%) of birds species have been estimated by the following expression:

Relative abundance $=\mathrm{n} / \mathrm{N} \times 100$

Where:

$\mathrm{n}=$ The number of a particular detected bird species

$\mathrm{N}=$ The total number detected for overall species in each region

Bird Diversity Indices. Avian species diversity, species richness and species evenness in oil palm plantations at different regions were analysed by using Shannon-Wiener Diversity Index, Margalef's Richness Index, and Pielou's Evenness Index.

The Shannon-Wiener Diversity Index for each oil palm plantations was calculated by using the following equation:

$$
\mathrm{H}=-\sum\left[\left(\mathrm{p}_{\mathrm{i}}\right) * \ln \left(\mathrm{p}_{\mathrm{i}}\right)\right]
$$

Where:

$\mathrm{S}=$ number of individuals of one species

$\mathrm{N}=$ total number of all individuals in the sample

Margalef's Richness Index was used as a simple measure of species richness.

$$
\mathrm{R}_{1}=(\mathrm{S}-1) / \ln (\mathrm{N})
$$

Where:

$\mathrm{S}=$ total number of species

$\mathrm{N}=$ total number of individuals in the samples

For calculating the evenness of species, the Pielou's Evenness Index was used.

$$
\mathrm{E}=\mathrm{H} / \ln (\mathrm{S})
$$

Where:

$\mathrm{H}=$ Shannon-Wiener Diversity Index

$\mathrm{S}=$ total number of species in the sample

Significant Difference among Different Oil Palm Plantations. A One-Way Analysis of Variance (ANOVA) and Tukey's (HSD) test was conducted in order to investigate the difference in bird richness and oil palm plantations at different regions.

\section{RESULTS}

Bird Species Composition with Relative Abundance in Different Oil Palm Plantations. Generally, the point count method observed a number of 2722 bird individuals representing 86 species of birds and 38 families (i.e 60.53\% families from Teluk Panglima Garang-Pulau Carey, 
68.42\% from Banting-Jenjarom, and 86.84\% from Sungai Pelek). 37 species were observed from oil palm plantation in Teluk Panglima Garang-Pulau Carey while 41 species were observed in Banting-Jenjarom and 65 bird species were observed in Sungai Pelek.

Bird Species Composition with Relative Abundance in Teluk Panglima Garang-Pulau Carey Oil Palm Plantation. A total of 1134 individuals were observed (40.18\%) from Teluk Panglima Garang-Pulau Carey representing 37 bird species and 23 families. Three bird species i.e., Orthotomus sutorius - Common Tailorbird (11.20\%), Acridotheres tristis - Common Myna (11.11\%), and Spilopelia chinensis - Spotted Dove (9.26\%) were the most common bird species in the Teluk Panglima Garang-Pulau Carey oil palm plantation. Conversely, two bird species i.e., Centropus bengalensis - Lesser Coucal and Prinia rufescens - Rufescent Prinia were least abundant (each $0.18 \%$ - observed only twice) (Table 1 ).

Bird Species Composition with Relative Abundance in Banting-Jenjarom Oil Palm Plantation. In Banting-Jenjarom oil palm plantation, a total of 1057 individuals of 41 species of birds were observed representing 26 families. The results showed that O. sutorius - Common Tailorbird (12.77\%), Copsychus saularis - Oriental Magpie-robin (11.92\%), and Geopelia striata Zebra Dove (9.84\%) were the most abundant bird species in Banting-Jenjarom oil palm plantation. On the contrarily, one species namely Pycnonotus brunneus - Asian Red-eyed Bulbul were considered as the rarest $(0.09 \%)$ (Table 1$)$.

Bird Species Composition with Relative Abundance in Sungai Pelek Oil Palm Plantation. Similarly, a total of 530 individuals of birds belonging to 65 species and 33 families were observed from oil palm plantation in Sungai Pelek. Three bird species i.e.; Halcyon smyrnensis - Whitethroated Kingfisher (12.81\%), A. tristis - Common Myna (9.04\%), and Pycnonotus goiavier Yellow-vented Bulbul (8.85\%) were the most abundant birds species observed with higher number of individuals. In addition, 10 species of birds such as Orthotomus ruficeps - Ashy Tailorbird, Aviceda leuphotes - Black Baza, Monticola solitarius - Blue Rock Thrush, Anthreptes malacensis Brown-throated Sunbird, Orthotomus atrogularis - Dark-necked Tailorbird, Dicrurus paradiseus Greater Racket-tailed Drongo, Aegithina viridissima - Green Iora, Pycnonotus eutilotus - Puffbacked Bulbul, Rhipidura albicollis - White-throated Fantail, and Ixobrychus sinensis - Yellow Bittern were the birds that considered as rare in oil palm plantation in Sungai Pelek (0.19\% each) (Table 1).

Comparison of Bird Species Composition in Oil Palm Plantations at Different Regions. 56 species of birds have been observed from oil palm plantations in Teluk Panglima Garang-Pulau Carey and Banting-Jenjarom. However, 15 species of birds were sampled only in oil palm plantations in Teluk Panglima Garang-Pulau Carey which were absent in oil palm plantations in Banting-Jenjarom. Reciprocally, 19 bird species were observed in oil palm plantations in BantingJenjarom, but absent in oil palm plantations in Teluk Panglima Garang-Pulau Carey. There were 21 bird species commonly detected in oil palm plantations in Teluk Panglima Garang-Pulau Carey and Banting Jenjarom (Table 1).

Comparing Teluk Panglima Garang-Pulau Carey and Sungai Pelek, 26 bird species were common in both habitats, 10 bird species were only found in the oil palm plantations at Teluk Panglima Garang-Pulau Carey; not found at all in the oil palm plantations at Sungai Pelek. Similarly, 38 species of birds were found in Sungai Pelek but were absent atTeluk Panglima Garang-Pulau Carey (Table 1).

Comparing oil palm plantations in Banting-Jenjarom and Sungai Pelek; 23 species were commonly found in both habitats. Only 17 species were detected in the oil palm plantations in Banting-Jenjarom but not found in oil palm plantations at Sungai Pelek. On the other hand, 41 
species were found in oil palm at Sungai Pelek but absent in oil palm at Banting-Jenjarom (Table 1).

Comparing results of the One-way ANOVA test showed there was a statistically significant difference between the avian relative abundance of the different regions $\left(\mathrm{F}_{2,170}=5.68, \mathrm{p}=0.041\right)$. Tukey's (HSD) test revealed that the avian relative abundance in oil palm plantations was significantly higher in Teluk Panglima Garang-Pulau Carey $(13.19 \pm 1.68$ birds, $\mathrm{p}<0.05)$ and Banting-Jenjarom $(12.29 \pm 1.65$ birds, $\mathrm{p}<0.05)$ compared to Sungai Pelek $(6.17 \pm 0.96$ birds $)$. However, there was no significant difference between Teluk Panglima Garang-Pulau Carey and Banting Jenjarom $(\mathrm{p}>0.05)$.

Table 1. Bird species composition with relative abundance in oil palm plantations at three different regions in Selangor,

\begin{tabular}{|c|c|c|c|c|c|c|c|c|}
\hline \multirow[b]{2}{*}{ Family } & \multirow[b]{2}{*}{ Scientific name } & \multirow[b]{2}{*}{ Common name } & \multicolumn{2}{|c|}{$\begin{array}{c}\text { Teluk Panglima Garang- } \\
\text { Pulau Carey } \\
\end{array}$} & \multicolumn{2}{|c|}{ Banting-Jenjarom } & \multicolumn{2}{|c|}{ Sungai Pelek } \\
\hline & & & No. of captures & $\%$ & $\begin{array}{c}\text { No. of } \\
\text { captures }\end{array}$ & $\%$ & $\begin{array}{c}\text { No. of } \\
\text { captures }\end{array}$ & $\%$ \\
\hline Cisticolidae & Orthotomus sutorius & Common Tailorbird & 127 & 11.20 & 135 & 12.77 & 0 & 0.00 \\
\hline Sturnidae & Acridotheres tristis & Common Myna & 126 & 11.11 & 87 & 8.23 & 48 & 9.04 \\
\hline Columbidae & Spilopelia chinensis & Spotted Dove & 105 & 9.26 & 55 & 5.20 & 24 & 4.52 \\
\hline Accipitridae & Spilornis cheela & Crested Serpent Eagle & 88 & 7.76 & 38 & 3.60 & 19 & 3.58 \\
\hline Sturnidae & Acridotheres javanicus & Javan Myna & 80 & 7.05 & 51 & 4.82 & 0 & 0.00 \\
\hline Muscicapidae & Copsychus saularis & $\begin{array}{l}\text { Oriental Magpie- } \\
\text { robin }\end{array}$ & 71 & 6.26 & 126 & 11.92 & 40 & 7.53 \\
\hline Halcyonidae & Halcyon smyrnensis & $\begin{array}{l}\text { White-throated } \\
\text { Kingfisher }\end{array}$ & 69 & 6.08 & 46 & 4.35 & 68 & 12.81 \\
\hline Oriolidae & Oriolus chinensis & Black-naped Oriole & 65 & 5.73 & 40 & 3.78 & 10 & 1.88 \\
\hline Pycnonotidae & Pycnonotus goiavier & $\begin{array}{l}\text { Yellow-vented } \\
\text { Bulbul }\end{array}$ & 62 & 5.47 & 100 & 9.46 & 47 & 8.85 \\
\hline Cuculidae & $\begin{array}{l}\text { Eudynamys } \\
\text { scolopaceus }\end{array}$ & Asian Koel & 57 & 5.03 & 0 & 0.00 & 4 & 0.75 \\
\hline Columbidae & Geopelia striata & Zebra Dove & 56 & 4.94 & 104 & 9.84 & 18 & 3.39 \\
\hline Phasianidae & Gallus gallus & Red Junglefowl & 42 & 3.70 & 15 & 1.42 & 6 & 1.13 \\
\hline Cisticolidae & Orthotomus ruficeps & Ashy Tailorbird & 35 & 3.09 & 26 & 2.46 & 1 & 0.19 \\
\hline Rallidae & $\begin{array}{l}\text { Amaurornis } \\
\text { phoenicurus }\end{array}$ & $\begin{array}{l}\text { White-breasted } \\
\text { Waterhen }\end{array}$ & 19 & 1.68 & 15 & 1.42 & 19 & 3.58 \\
\hline Cisticolidae & $\begin{array}{l}\text { Orthotomus } \\
\text { atrogularis }\end{array}$ & $\begin{array}{l}\text { Dark-necked } \\
\text { Tailorbird }\end{array}$ & 13 & 1.15 & 0 & 0.00 & 1 & 0.19 \\
\hline Cisticolidae & Prinia flaviventris & Yellow-bellied Prinia & 10 & 0.88 & 0 & 0.00 & 4 & 0.75 \\
\hline Pycnonotidae & Tricholestes criniger & Hairy-backed Bulbul & 8 & 0.71 & 0 & 0.00 & 0 & 0.00 \\
\hline Rhipiduridae & Rhipidura albicollis & $\begin{array}{l}\text { White-throated } \\
\text { Fantail }\end{array}$ & 8 & 0.71 & 0 & 0.00 & 1 & 0.19 \\
\hline Nectariniidae & Leptocoma calcostetha & $\begin{array}{l}\text { Copper-throated } \\
\text { Sunbird }\end{array}$ & 8 & 0.71 & 7 & 0.66 & 0 & 0.00 \\
\hline Ardeidae & Ardea purpurea & Purple Heron & 8 & 0.71 & 0 & 0.00 & 9 & 1.69 \\
\hline Corvidae & Corvus splendens & House Crow & 7 & 0.62 & 0 & 0.00 & 9 & 1.69 \\
\hline Coraciidae & Eurystomus orientalis & Dollarbird & 7 & 0.62 & 7 & 0.66 & 8 & 1.51 \\
\hline Timaliidae & Mixornis gularis & $\begin{array}{l}\text { Pin-striped Tit- } \\
\text { babbler }\end{array}$ & 7 & 0.62 & 11 & 1.04 & 0 & 0.00 \\
\hline Halcyonidae & Todiramphus chloris & Collared Kingfisher & 6 & 0.53 & 17 & 1.61 & 2 & 0.38 \\
\hline Estrildidae & Lonchura punctulata & Scaly-breasted Munia & 6 & 0.53 & 7 & 0.66 & 8 & 1.51 \\
\hline Corvidae & $\begin{array}{l}\text { Corvus } \\
\text { macrorhynchos }\end{array}$ & Large-billed Crow & 5 & 0.44 & 11 & 1.04 & 0 & 0.00 \\
\hline Scolopacidae & Gallinago stenura & Pin-tailed Snipe & 5 & 0.44 & 0 & 0.00 & 0 & 0.00 \\
\hline Rhipiduridae & Rhipidura javanica & $\begin{array}{l}\text { Malaysian Pied } \\
\text { Fantail }\end{array}$ & 5 & 0.44 & 0 & 0.00 & 5 & 0.94 \\
\hline Muscicapidae & Ficedula mugimaki & Mugimaki Flycatcher & 5 & 0.44 & 0 & 0.00 & 0 & 0.00 \\
\hline Laniidae & Lanius cristatus & Brown Shrike & 4 & 0.35 & 0 & 0.00 & 8 & 1.51 \\
\hline Charadriidae & Vanellus malabaricus & $\begin{array}{l}\text { Yellow-wattled } \\
\text { Lapwing }\end{array}$ & 4 & 0.35 & 0 & 0.00 & 5 & 0.94 \\
\hline Hirundinidae & Hirundo rustica & Barn Swallow & 3 & 0.26 & 7 & 0.66 & 6 & 1.13 \\
\hline Meropidae & Merops philippinus & Blue-tailed Bee-eater & 3 & 0.26 & 14 & 1.32 & 12 & 2.26 \\
\hline Scolopacidae & Calidris alpina & Dunlin & 3 & 0.26 & 0 & 0.00 & 0 & 0.00 \\
\hline Charadriidae & Charadrius dubius & Little Ringed Plover & 3 & 0.26 & 8 & 0.76 & 0 & 0.00 \\
\hline Cisticolidae & Prinia rufescens & Rufescent Prinia & 2 & 0.18 & 0 & 0.00 & 3 & 0.56 \\
\hline Cuculidae & Centropus bengalensis & Lesser Coucal & 2 & 0.18 & 0 & 0.00 & 5 & 0.94 \\
\hline Meropidae & Merops viridis & $\begin{array}{l}\text { Blue-throated Bee- } \\
\text { eater }\end{array}$ & 0 & 0.00 & 14 & 1.32 & 0 & 0.00 \\
\hline Estrildidae & Lonchura maja & White-headed Munia & 0 & 0.00 & 14 & 1.32 & 0 & 0.00 \\
\hline Estrildidae & Lonchura atricapilla & Chestnut Munia & 0 & 0.00 & 14 & 1.32 & 2 & 0.38 \\
\hline Aegithinidae & Aegithina viridissima & Green Iora & 0 & 0.00 & 10 & 0.95 & 1 & 0.19 \\
\hline Nectariniidae & Anthreptes malacensis & $\begin{array}{l}\text { Brown-throated } \\
\text { Sunbird }\end{array}$ & 0 & 0.00 & 9 & 0.85 & 1 & 0.19 \\
\hline
\end{tabular}




\begin{tabular}{|c|c|c|c|c|c|c|c|c|}
\hline Dicaeidae & $\begin{array}{l}\text { Prionochilus } \\
\text { thoracicus }\end{array}$ & $\begin{array}{l}\text { Scarlet-breasted } \\
\text { Flowerpecker }\end{array}$ & 0 & 0.00 & 9 & 0.85 & 0 & 0.00 \\
\hline Picidae & $\begin{array}{l}\text { Chrysocolaptes } \\
\text { guttacristatus }\end{array}$ & Greater Flameback & 0 & 0.00 & 7 & 0.66 & 0 & 0.00 \\
\hline Cuculidae & Phaenicophaeus diardi & $\begin{array}{l}\text { Black-bellied } \\
\text { Malkoha }\end{array}$ & 0 & 0.00 & 6 & 0.57 & 0 & 0.00 \\
\hline Accipitridae & Nisaetus alboniger & Blyth's Hawk-eagle & 0 & 0.00 & 6 & 0.57 & 0 & 0.00 \\
\hline Accipitridae & Haliastur indus & Brahminy Kite & 0 & 0.00 & 6 & 0.57 & 4 & 0.75 \\
\hline Megalaimidae & $\begin{array}{l}\text { Megalaima } \\
\text { haemacephala }\end{array}$ & Coppersmith Barbet & 0 & 0.00 & 6 & 0.57 & 0 & 0.00 \\
\hline Campephagidae & $\begin{array}{l}\text { Pericrocotus } \\
\text { divaricatus }\end{array}$ & Ashy Minivet & 0 & 0.00 & 5 & 0.47 & 4 & 0.75 \\
\hline Alcedinidae & Alcedo atthis & Common Kingfisher & 0 & 0.00 & 5 & 0.47 & 0 & 0.00 \\
\hline Columbidae & Columba livia & Rock Pigeon & 0 & 0.00 & 4 & 0.38 & 2 & 0.38 \\
\hline Accipitridae & Butastur indicus & Grey-faced Buzzard & 0 & 0.00 & 5 & 0.47 & 0 & 0.00 \\
\hline Cuculidae & Centropus sinensis & Greater Coucal & 0 & 0.00 & 4 & 0.38 & 6 & 1.13 \\
\hline Accipitridae & Nisaetus cirrhatus & $\begin{array}{l}\text { Changeable Hawk } \\
\text { Eagle }\end{array}$ & 0 & 0.00 & 3 & 0.28 & 4 & 0.75 \\
\hline Pellorneidae & Trichastoma rostratum & $\begin{array}{l}\text { White-chested } \\
\text { Babbler }\end{array}$ & 0 & 0.00 & 3 & 0.28 & 0 & 0.00 \\
\hline Pycnonotidae & Pycnonotus brunneus & $\begin{array}{l}\text { Asian Red-eyed } \\
\text { Bulbul }\end{array}$ & 0 & 0.00 & 1 & 0.09 & 0 & 0.00 \\
\hline Accipitridae & Elanus axillaris & $\begin{array}{l}\text { Black-shouldered } \\
\text { Kite }\end{array}$ & 0 & 0.00 & 0 & 0.00 & 15 & 2.82 \\
\hline Ardeidae & Ardea cinerea & Grey Heron & 0 & 0.00 & 0 & 0.00 & 10 & 1.88 \\
\hline Accipitridae & Pernis ptilorhyncus & $\begin{array}{l}\text { Crested Honey } \\
\text { Buzzard }\end{array}$ & 0 & 0.00 & 0 & 0.00 & 9 & 1.69 \\
\hline Ardeidae & $\begin{array}{l}\text { Ixobrychus } \\
\text { cinnamomeus }\end{array}$ & Cinnamon Bittern & 0 & 0.00 & 0 & 0.00 & 9 & 1.69 \\
\hline Picidae & Dinopium javanense & Common Flameback & 0 & 0.00 & 0 & 0.00 & 6 & 1.13 \\
\hline Sturnidae & Aplonis panayensis & Asian Glossy Starling & 0 & 0.00 & 0 & 0.00 & 5 & 0.94 \\
\hline Campephagidae & Lalage nigra & Pied Triller & 0 & 0.00 & 0 & 0.00 & 5 & 0.94 \\
\hline Dicruridae & Dicrurus leucophaeus & Ashy Drongo & 0 & 0.00 & 0 & 0.00 & 5 & 0.94 \\
\hline Columbidae & Treron vernans & $\begin{array}{l}\text { Pink-necked Green } \\
\text { Pigeon }\end{array}$ & 0 & 0.00 & 0 & 0.00 & 5 & 0.94 \\
\hline Hemiprocnidae & Hemiprocne comata & Whiskered Treeswift & 0 & 0.00 & 0 & 0.00 & 4 & 0.75 \\
\hline Charadriidae & Vanellus indicus & Red-wattled Lapwing & 0 & 0.00 & 0 & 0.00 & 4 & 0.75 \\
\hline Anatidae & Dendrocygna javanica & $\begin{array}{l}\text { Lesser Whistling- } \\
\text { duck }\end{array}$ & 0 & 0.00 & 0 & 0.00 & 3 & 0.56 \\
\hline Tytonidae & Tyto alba & Common Barn Owl & 0 & 0.00 & 0 & 0.00 & 3 & 0.56 \\
\hline Corvidae & Corvus enca & Slender-billed Crow & 0 & 0.00 & 0 & 0.00 & 3 & 0.56 \\
\hline Scolopacidae & Philomachus pugnax & Ruff & 0 & 0.00 & 0 & 0.00 & 3 & 0.56 \\
\hline Pycnonotidae & Ixos malaccensis & Streaked Bulbul & 0 & 0.00 & 0 & 0.00 & 3 & 0.56 \\
\hline Meropidae & Merops orientalis & $\begin{array}{l}\text { Little Green Bee- } \\
\text { eater }\end{array}$ & 0 & 0.00 & 0 & 0.00 & 3 & 0.56 \\
\hline Ardeidae & Egretta garzetta & Little Egret & 0 & 0.00 & 0 & 0.00 & 3 & 0.56 \\
\hline Apodidae & Apus nipalensis & House Swift & 0 & 0.00 & 0 & 0.00 & 2 & 0.38 \\
\hline Ciconiidae & Mycteria leucocephala & Painted Stork & 0 & 0.00 & 0 & 0.00 & 2 & 0.38 \\
\hline Picidae & $\begin{array}{l}\text { Micropternus } \\
\text { brachyurus }\end{array}$ & Rufous Woodpecker & 0 & 0.00 & 0 & 0.00 & 2 & 0.38 \\
\hline Dicaeidae & Dicaeum minullum & Plain Flowerpecker & 0 & 0.00 & 0 & 0.00 & 2 & 0.38 \\
\hline Ardeidae & Butorides striata & Little Heron & 0 & 0.00 & 0 & 0.00 & 2 & 0.38 \\
\hline Strigidae & Strix seloputo & Spotted Wood Owl & 0 & 0.00 & 0 & 0.00 & 2 & 0.38 \\
\hline Falconidae & $\begin{array}{l}\text { Microhierax } \\
\text { fringillarius }\end{array}$ & $\begin{array}{l}\text { Black-thighed } \\
\text { Falconet }\end{array}$ & 0 & 0.00 & 0 & 0.00 & 2 & 0.38 \\
\hline Accipitridae & Aviceda leuphotes & Black Baza & 0 & 0.00 & 0 & 0.00 & 1 & 0.19 \\
\hline Muscicapidae & Monticola solitarius & Blue Rock Thrush & 0 & 0.00 & 0 & 0.00 & 1 & 0.19 \\
\hline Dicruridae & Dicrurus paradiseus & $\begin{array}{l}\text { Greater Racket-tailed } \\
\text { Drongo }\end{array}$ & 0 & 0.00 & 0 & 0.00 & 1 & 0.19 \\
\hline Ardeidae & Ixobrychus sinensis & Yellow Bittern & 0 & 0.00 & 0 & 0.00 & 1 & 0.19 \\
\hline Pycnonotidae & Pycnonotus eutilotus & $\begin{array}{l}\text { Puff-backed Bulbul } \\
\text { Total }\end{array}$ & $\begin{array}{c}0 \\
1134\end{array}$ & 0.00 & $\begin{array}{c}0 \\
1057\end{array}$ & 0.00 & $\begin{array}{c}1 \\
531\end{array}$ & 0.19 \\
\hline
\end{tabular}

Comparison of Bird Diversity Indices in Oil Palm Plantations at Different Regions. Analysis showed that the diversity of bird species in oil palm plantations at Sungai Pelek is more diverse (Shannon-Wiener Diversity Index H; 3.52) and richest in avian species (Margalef's Richness Index $\mathrm{R}_{1}$; 10.2) compared to both oil palm plantations in Teluk Panglima Garang-Pulau Carey and Banting-Jenajrom. However, avian species in both oil palm plantations in Teluk Panglima GarangPulau Carey and Banting-Jenjarom were most evenly distributed (Pielou's Evenness Index E; 0.82) compared to the oil palm plantations in Sungai Pelek (Table 2). 
Table 2. Diversity indices of bird species in oil palm plantations at three different regions in Selangor, Malaysia

\begin{tabular}{lllll}
\hline & \multicolumn{2}{l}{ Shannon-Wiener Diversity Index } & Margalef's Richness Index & Pielou's Evenness Index \\
$\mathrm{R}_{1}$ & $\mathrm{H}$ & \\
Habitat & & $\mathrm{H}$ & 5.12 & 0.82 \\
\hline Teluk Panglima & Garang-Pulau & 2.96 & 5.74 & 0.82 \\
Carey & & 10.2 & 0.84 \\
Banting-Jenjarom & 3.05 & 3.52 & & \\
Sungai Pelek & & & & \\
\hline
\end{tabular}

\section{DISCUSSION}

Birds are bio-indicators of the health of ecosystems. They are more visible, easy to learn and are closely related to the vegetation structure. Birds often choose to utilize a variety of habitats and dependent on the quality and productivity of the habitat in terms of food availability, shelter, and breeding areas to maintain populations [19]. Monitoring bird association in monoculture plantations is important to understand the importance, productivity, and suitability of certain areas in influencing habitat selection and distribution of birds.

The number of bird species inventory in in the oil palm plantation at Teluk Panglima GarangPulau Carey, Banting-Jenjarom and Sungai Pelek was 37, 41 and 65 respectively. By referring to the result, Sungai Pelek has the highest species richness when compared to the other two areas. However, the total number of individuals at that area recorded a lowest at 531 compared to 1134 and 1057 in Teluk Panglima Garang-Pulau Carey and Banting-Jenjarom. Therefore, we can say that the vicinity of the oil palm plantations at the Sungai Pelek provide better habitats for birds. Apart from close to the mangroves and Bagan Lalang Beach, the location of oil palm plantations is also close to the edge of forest. Moreover, residents in Sungai Pelek are active in planting activity including vegetables, fruits, as well as cassava and sweet potatoes. The vegetables gardens and orchards are cultivated massively not far from the oil palm plantations. There are also abandoned plantations between the oil palm plantations. Some of the plantations also have pond and drains that flows clean water. Based on [20], the characteristics of the adjacent landscapes of the oil palm plantation such as mangroves, forests, and near water bodies can promote high diversity and species richness due to the wide diversity of habitat characteristics and increase in prey availability. However, the observations hint that most of the species recorded in Sungai Pelek showed the behaviour of movement in oil palm plantation instead of foraging and nesting. This is the factor that causes the number of individuals observed in oil palm plantation at Sungai Pelek is lower than the other two places.

Food sources may regulate population distribution of bird species [21], and fruits abundance may affect species composition and foraging behaviour of frugivorous birds [22]. Opening gaps will increase shrub that often leads in growth of variety of flowers and fruits, which is the main diet for bird species. Tree diversity and richness may also affect the provision and utilization of the food and ultimately affect the distribution and diversity of birds. Based on [23], different bird species would be attracted to the different vegetation structure such as large area of seedlings, regenerating or early successional plants for their food sources [24]. For example, frugivorous birds are always concentrated where fruits are abundance, as their diet consisted of more than $50 \%$ of fruits [25]. From the observation, $24.4 \%$ from the total of 86 species of birds are frugivorous. [26] stated that deforestation causes gaps that enhance the growth of shrubs that would attract understorey bird species such as Common Tailorbird and Common Myna.

The results of a larger number of tailorbird, myna, dove, robin, and bulbul in oil palm plantations in Teluk Panglima Garang-Pulau Carey and Banting-Jenjarom shows that forest logging is one of the key determinants of richness effects and the distribution of this bird species [27]. We also can assume that these species of birds are not affected by the disturbance. These avian species are considered as open country birds and utilized open area such as parks, gardens, and plantations.

[23] reported that the diversity of songbird species will increased in harvested area. They often choose internal edges, clearings, and forest logging areas [28]. 44.2\% of bird species discovered at the oil palm plantation in Teluk Panglima Garang-Pulau Carey, Banting-Jenjarom, and Sungai Pelek were Passeriformes. 
Contrarily, observation of several rarest species at oil palm plantation of Banting-Jenjarom and Sungai Pelek such as Asian Red-eyed Bulbul, Black Baza, Blue Rock Thrush, Greater Racket-tailed Drongo, Puff-backed Bulbul, and Yellow Bittern shows that these bird species are less resilience to disturbance and are habitat specialist.

Regarding the status of birds, there are 57 resident bird species, 15 resident and migratory bird species, 9 migratory bird species, 4 feral bird species, and 1 vagrant bird species observed at the oil palm plantations in Teluk Panglima Garang-Pulau Carey, Banting-Jenjarom, and Sungai Pelek. In the case of migratory birds, there are 5 species of migratory birds had been observed present at both oil palm plantations in Teluk Panglima Garang-Pulau Carey and Sungai Pelek, whereas 4 species of migratory birds had been observed at oil palm plantations in Banting-Jenjarom. This indicates that the numbers of bird species that benefit from the areas are almost the same.

Overall, these findings indicate that the bird community is dynamic and can change in relation to the deforestation, conversion from forest to monotonous plantation or the vicinity of the particular area. Deforestation creates canopy gaps by the removal of trees and the establishment of the plantation causes less plant diversity and hence influence the richness and diversity of birds through food sources, increased in nest predation, and brood parasitism [29]. Our result also suggest that, despite the relatively oil palm plantation is adjacent to the mangrove, oil palm plantations are relatively impermeable habitat for many species of birds, including species of high conservation value. For more effective conservation of birds in oil palm plantations, the larger forest patches are needed in the landscapes. Moreover, whenever possible, more oil palm plantations should be developed adjacent to one or more larger continuous areas of forest, which could be a source of habitat. This further indicates that in order to increase the value of forest patches for bird diversity and conservation in oil palm plantations, quality of habitat is one of the key factors that needed to be repaired.

\section{CONCLUSION}

The vegetation structure and the vicinity on that particular area may affect the distribution of bird species. There are bird species identified of which listed as Nearly Threatened (NT) at oil palm plantations in Banting-Jenjarom and Sungai Pelek based on [30]. The species are Green Iora (Aegithina viridissima), Scarlet-breasted Flowerpecker (Prionochilus thoracicus), Black-bellied Malkoha (Phaenicophaeus diardi), White-chested Babbler (Trichastoma rostratum), Streaked Bulbul (Ixos malaccensis), Painted Stork (Mycteria leucocephala), and Puff-backed Bulbul (Pycnonotus eutilotus). Those species should therefore have high priority for conservation and monitoring. The inventories of bird species in the oil palm plantation may be useful in predicting the bird changes under various human disturbances, and ultimately protecting the Malaysian avifauna.

\section{Acknowledgement}

I would like to thank Assoc. Prof. Dr. Hafidzi Mohd Noor; my PhD supervisor that gives much impetus to the success of this study. Do not to forget, Mr. Kamarul Ariffin Hambali, Mr. Asrul Sani, and the villagers of the study area that were greatly assist the worked. This appreciation also accorded to Universiti Putra Malaysia and Universiti Malaysia Kelantan as giving me the opportunity to pursue study at the $\mathrm{PhD}$ level. 


\section{References}

[1] Rajpar, M.N. and M. Zakaria. 2011. Bird species abundance and their correlationship with microclimate and habitat variables at natural wetland reserve, Peninsular Malaysia. International J. Zoology, Article ID 758573, 17 pages.

[2] Malaysian Nature Society. 2010. Checklist of the Malaysian birds with information about occurrence and status. URL: http://www.birdingmalaysia.com/lists.php. Retrieved on $23^{\text {rd }}$ April 2015.

[3] Koh, L.P. and Wilcove, D. S. 2009. Oil palm: disinformation enables deforestation. Trends in Ecology and Evolution 24: 67-68.

[4] Koh, L.P. and Wilcove, D.S. 2008. Is oil palm agriculture really destroying tropical biodiversity? Conservation Letters 1: 60-64.

[5] Peh, K.S.H., Sodhi, N.S., Jong, J.D., Sekercioglu, C.H., Yap, C.A.M. and Lim, S.L.H. 2006. Conservation value of degraded habitats for forest birds in Southern Peninsular Malaysia. Diversity and Distribution 12: 572-581.

[6] White, J.G, Antos, M.J., Fitzsimons, J.A, Palmer, G.C. 2005. Non-uniform bird assemblages in urban environments: the influence of streetscape vegetation. Landscape and Urban Planning, 71: 123-135.

[7] Shahabuddin, G., Kumar, R. 2007. Effects of extractive disturbance on bird assemblages, vegetation structure and floristics in tropical scrub forest, Sariska Tiger Reserve, India. Forest Ecology and Management. 246 (2-3): 175-185.

[8] Tabarelli, M., Aguiar, A.V., Ribeiro, M.C., Metzger, J.P., Peres, C.A. 2010. Prospects for biodiversity conservation in the Atlantic Forest: Lessons from aging human-modified landscapes. Biological Conservation 143: 2328-2340.

[9] Kukreti, M. and Bhatt, D. 2014. Birds of Lansdowne forest division and adjacent suburban landscapes, Garhwal Himalayas, Uttarakhand, India: community structure and seasonal distribution. Biodiversitas 15: 80-88.

[10] World Bank Report. 2013. Bird species; threatened in Malaysia. Retrieved on $13^{\text {th }}$ April 2015 at URL: http://ieconomics.com/bird-species-threatened-in-malaysia

[11] Yaap, B., Struebig, M., Paoli, G. and Koh, L. 2010. Mitigating the biodiversity impacts of oil palm development. CAB Reviewers: Perspectives in Agriculture, Veterinary Science, Nutrition and Natural Resources 5: 1-11.

[12] RSPO. 2013. RSPO Principles and Criteria for Sustainable Palm Oil Production. 70 pp. www.rspo.org/file/PnC_RSPO_Rev1.pdf. Accesssed on 27 $7^{\text {th }}$ March 2015.

[13] Azhar, B., Lindenmayer, D.B., Wood, J., Fischer, J., Manning, A., McElhinny, C. and Zakaria, M. 2011. The conservation value of oil palm plantation estates, small holdings and logged peat swamp forest for birds. Forest Ecology and Management 262: 2306-2315.

[14] Edwards, D.P., Hodgson, J.A., Hamer, K.C., Mitchell, S.L., Ahmad, A.H., Cornell, S.J. and Wilcove, D.S. 2010. Wildlife-friendly oil palm plantations fail to protect biodiversity effectively. Conservation Letters 3: 236-242.

[15] Peh, K.S.H., de Jong, J., Navjot, S.S., Susan, L.H.L., Charlotte, A.M.Y. 2005. Lowland rainforest avifauna and human disturbance: Persistence of primary forest birds in selectively logged forests and mixed-rura; habitats of southern Peninsular Malaysia. Biological Conservation, Elsevier. 
[16] Rajpar, M.N., and Zakaria, M. 2010. Density and diversity of water birds and terrestrial birds at Paya Indah Wetland Reserve, Selangor, Peninsular Malaysia. Journal of Biological Science. Vol. 10, ed. 7, pp. 658-666.

[17] Kwok, H.K., Corlett, R.T. 2000. The bird community of a natural secondary forest and a Lophostemon confertus plantation in Hong Kong, South China. Forest Ecology and Management. Vol. 130,pp. 227-234.

[18] Scharringa, J. 2005. CD-ROM of birds of tropical Asia 3. Bird Song International. Netherland. 2005.

[19] Soderstrom, B. and T. Part. 2000. Influence of landscape scale on farmland birds in seminatural pastures. Conser. Biol., 14: 522-533.

[20] Cintra, R. and L.N. Naka. 2012. Spatial variation in bird community composition in relation to topographic gradient and forest heterogeneity in a Central Amazonian Rainforest. Intl. J. Ecology.

[21] Johnson, M.D. and T.W. Sherry. 2001. Effects of food availability on the distribution of migratory warblers among habitats in Jamaica. J. Anim, Ecol., 70: 546-560.

[22] Moegenburg, S.M. and D.J. Levey. 2003. Do frugivore respond to fruit harvest? An experimental study of short-term response. Ecology, 84: 2600-2612.

[23] Campbell, S.P., J.W. Witham and M.L. Hunter Jr., 2007. Long-term effects of group selection timber harbesting on abundance of forest birds. Conserv. Biol., 21: 1218-1229.

[24] DeGraaf, R.M. and M. Yamasaki. 2003. Options for managing early successional forest and shrubland bird habitats in the north-eastern United States. Forest Ecol. Manage., 185: 179191.

[25] Renton, K. 2001. Lilac-crowned Parrot diet and food resource availability: Resource tracking by a parrot seed predator. Condor, 103: 62-69.

[26] Doyon, F., D. Gagnon and J.F. Giroux. 2005. Effects of strip and single tree selection cutting on birds and their habitat in a South-Western Quebec Northern Hardwood forest. Forest Ecol. Manag., 209: 101-115.

[27] McShea, W.J. and J.H. Rappole. 2000. Managing the abundance and diversity of breeding bird populations through manipulation of deer populations. Conserv. Biol., 14: 1161-1170.

[28] King, D.I. and R.M. Degraff. 2004. Effects of group selection opening size on the distribution and reproductive success of an early-successional shrubland birds. Forest Ecol. Manage., 190: $179-185$.

[29] Lemelin, L.V., L. Imbeau, M. Darveau, and D. Bordage. 2007. Local, short-term effects of forest harvesting on breeding waterfowl and Common Loon in forest-dominant landscapes of Quebec. Avian Conserv. Ecol. 2:pp. 10.

[30] IUCN 2014. The IUCN Red List of Threatened Species. Version 2014.3. 